\title{
Research on the Influence of Political Correlation of Private Listed Companies on Corporate Social Responsibility Behavior*
}

\author{
Zhihong Fu \\ School of Business Administration, South China University of Technology, Guangzhou, China \\ Email: Alicefzh@163.com
}

How to cite this paper: Fu, Z.H. (2019) Research on the Influence of Political Correlation of Private Listed Companies on Corporate Social Responsibility Behavior. American Journal of Industrial and Business Management, 9, 579-591.

https://doi.org/10.4236/ajibm.2019.93040

Received: March 5, 2019

Accepted: March 17, 2019

Published: March 20, 2019

Copyright (c) 2019 by author(s) and Scientific Research Publishing Inc. This work is licensed under the Creative Commons Attribution International License (CC BY 4.0).

http://creativecommons.org/licenses/by/4.0/ Open Access

\begin{abstract}
Based on the perspective of legitimacy, this paper uses the Logistic and OLS regression methods to analyze the relationship between the release of CSR reports issued by private companies from 2010 to 2016 and the relationship between report quality and executive political connections. The analysis shows that executive political relations can significantly affect the quality of private companies in the CSR report release and publication possibility of CSR report. According to the analysis results, the paper finally proposes how to promote corporate social responsibility by exerting the political correlation role of executives. Through theoretical and empirical research, it analyzes the influence of executive political association on corporate financial performance and social responsibility, and analyzes and verifies the role of regional marketization development process in private social responsibility behavior and political association formation motivation, thus making private enterprise politics rational use of related resources, standardizing and guiding the commitment of civil society's social responsibility, and providing corresponding policy recommendations for promoting healthy and sustainable economic development. Secondly, this study analyzes the influence of executive political connections on corporate social responsibility behavior from a multi-theoretical perspective, and provides more analytical perspectives for future related research.
\end{abstract}

\footnotetext{
${ }^{\star}$ This research is divided into five parts. The first part is the introduction, which mainly introduces the research background and research problems. The second part is the theoretical analysis and research hypothesis. Through the analysis of the theory and the previous research results, the research hypothesis of this paper is derived. The third part is the research design, which mainly introduces the selection of samples and the definition of each variable. The fourth part is the empirical test and analysis, which verifies the rationality of the research hypothesis through scientific methods. The fifth part is the research conclusion. The research results of this paper are analyzed and the future research improvement direction is analyzed.
} 


\section{Keywords}

Political Connection, Private Enterprise, Social Responsibility Behavior, Report Quality

\section{Introduction}

In recent years, with the development of economic globalization, the market and the public's criteria for judging whether a company is successful are no longer based on the short-term investment income and operating profit of the enterprise, and the Chinese government pays more attention to the harmonious development of the economy rather than pursuing a single value. Maximization has made corporate social responsibility highly valued by people from all walks of life and the government. Looking at the number of CSR reports released by all listed companies in each year in recent years, we find that the number of CSR reports released by China's listed companies has increased tremendously since 2010, and the growth rate is still very impressive in the next two years. Although due to the influence of the central government, these increased CSR report publishing enterprises account for a large part of the central government, since 2010, many private enterprises have voluntarily joined the ranks of CSR report release. Moreover, judging from the content of the CSR report that has been released, the quality of CSR reports varies from enterprise to enterprise.

And for what reason does the enterprise produce this spontaneous behavior, and what causes the difference in the quality of its report? The explanation given in previous studies is not perfect. Since China is in a period of economic transformation, China's private enterprises are faced with an uncertain external economic environment. Private enterprises have the motive to seek to establish political ties. They will pay more attention to the choice of corporate political strategy. Enterprises will invest in certain human and material resources. The relationship between the governments has won an advantage for the development of the company. Institutional scholars have suggested that because the government controls the key resources that determine the competitive position of companies in the industry (Baron 1995, Schuler and Rehbein 1997) [1] [2], companies will strategically address their relationship with the government in various ways (Hillman et al. 2004) [3]. In addition, many researchers argue that political legitimacy as a strategic resource can make it easier for companies to obtain government resources. As far as the current situation is concerned, the Chinese government has strengthened the requirements for corporate social responsibility, but there are no rigid rules and regulations that require private enterprises to issue social responsibility reports. It only transmits a message to the society through a series of activities or public statements that government hopes corporate take social responsibility. From a certain perspective, private enterprises spontaneously respond to the government's call, and the release of CSR reports is largely due to the pursuit of political legitimacy. In addition, the existence of the relationship 
between private enterprises and the government in China is universal, and the political connection of executives is very common. If the political relationship of executives is a strategic behavior taken by enterprises in order to obtain legitimacy, then the relationship between the release of executives' political connections and corporate social responsibility reports and decoupling will be beneficial to the changes in the market or economic environment. At the transitional stage, non-institutional means are used to guide corporate behavior. Based on this study, the relationship between the political relationship of executives and the publication and reporting quality of corporate social responsibility reports is studied from the perspectives of legality and institutional pressure.

\section{Theoretical Analysis and Research Hypothesis}

\subsection{Relationship of the Political Connection and Social Responsibility Report}

View from a resource-resource perspective, Pfeffer and Salancik (1978) [4] believe that the resources that are related to the company's sustainable development are often not owned by the company, and the company needs to take the least restrictive measures to improve the control of external key resources. And political connections are a way to reduce corporate constraints because the government can provide companies with political connections with lower tax rates and debt financing benefits (Fan, Wong and Zhang, 2007) [5]. Moreover, the phenomenon that executives of enterprises are or have been employed in government or localities is very common in China. Because China's economy is currently in a period of transition and there is a phenomenon of imperfect institutional environment, contracts are often based on relationships. Detomasi (2008) also believe that a country's institutional environment determines how companies approach the key resources of government control [6]. Therefore, in order to improve the survival rate of enterprises, enterprises will choose to establish formal or informal relations with the government through the executives to timely obtain resources that are beneficial to the survival or development of the enterprise. In addition to the political connections of executives, companies can more timely or comprehensively understand the extent to which authorities and stakeholders expect corporate social responsibility. Secondly, by improving the government's trust in the company and maintaining the political relationship between the company and the government, the company's ability to control key resources and legitimacy can be improved. Tian Lihui and Zhang Wei (2013) proposed that for private enterprises, political connections not only help property rights protection, but also help to obtain government care [7]. Zhang Jianjun and Zhang Zhixue (2005) proposed that because politically connected enterprises have gained a lot of interests through political connections, the government has greater expectations for its commitment to social responsibility [8]. The social responsibility report promoted by the government, as a carrier to show the good social image of the company, has received more and more attention and social influence. Therefore, in order to better maintain the relationship 
with the government and establish a good corporate image, companies with political connections are more likely to issue CSR reports in order to cater to the government. And from the point of view of the agency, executives will promote corporate social responsibility reports in order to obtain private benefits. Secondly, from the perspective of the value of private benefits brought by political connections to executives, political connections, as a kind of relational assets, not only bring benefits to the company, but also important social capital of executives and can bring private benefits to executives [9]. So in this case, companies with political connections also have a strong incentive to maintain relationships with government agencies in order to continue to benefit from relationships with the government. Therefore based on the above content, the following assumptions are made:

H1: Private enterprises with executive political connections are more likely to issue CSR reports.

\subsection{The Regulatory Role of Corporate Characteristics on the Political Relationship between Executives and the Release of CSR Reports}

According to the theory of resource dependence theory, the government often controls the key resources for the survival and development of enterprises. Therefore, in order to obtain such key resources, enterprises will consciously maintain good relations with the government. Therefore, they will respond positively to a series of signals from the government to make a good impression on the government and the public. From a legal point of view, because the government controls the key resources that can determine the competitive position of the company in the industry, the company regards the relationship between the government and the government as a strategic activity, so it will abide by the government's rules and regulations. Responding to some government-issued signals on specifications and standards to make it look more legitimate. Because this legitimacy makes it easy for companies to obtain resources from the government. Since the company was established at the beginning to make itself appear more legitimate, the construction of its internal mechanism will cater to the political system at the beginning of its establishment, that is, there is a path dependence among stakeholders. Barnett (2007) found through research that the government policy at the beginning of the establishment of the company had a great impact at the time of its establishment [10], and this influence will continue until later (Marquis and Tilcsik 2013) [11], that is, because of the establishment of the political system to the internal mechanism of the enterprise Construction has a big impact, so companies will continue to commit to establishing a political system that points to that era. Kriauciunas and Kale (2006) pointed out in their articles that there are such "social imprints" in the capital and knowledge resources of enterprises [12], and they have distinct characteristics of the times. The major change in China's economic system began in 2004, so for young companies, the old companies' past policies have a stronger social im- 
print, and they are less responsive to new policies than younger ones. Second, the financial status of the company will also have an impact on whether or not to issue a CSR report. Many researches show that older Chinese companies have good mechanisms and vested interests, so it is unlikely to respond to new management practices, such as appointing outside directors; in contrast, younger companies have more Strong motivation to establish their legitimacy, so they are more likely to implement new policies. Schuler and Rehbein (1997) argue that companies with good financial positions are better able to participate in political activities [2]. Hillman (2005) suggested that participating in political activities can bring greater returns to the company [13]. Seifert et al. (2004) found that the idle resources of enterprises have a very important impact on the participation of enterprises in social activities [14]. Based on the above, the following assumptions are made:

$\mathrm{H} 2 \mathrm{a}$ : The age of the company will negatively regulate the relationship between executive political relations and the release of CSR reports;

$\mathrm{H} 2 \mathrm{~b}$ : Corporate finances will positively adjust the relationship between executive political connections and CSR report releases.

\subsection{The Relationship between Executive Political Association and CSR Reporter Quality}

From the perspective of impression management, companies may use some public reports such as financial reports and CSR reports to manage their impressions, thereby enhancing their image in the public mind. At present, RSK has made a multi-dimensional score on the quality of CSR reports of enterprises. The level of this score can reflect the impression management behavior of enterprises and the degree of decoupling of enterprises in social responsibility. Originally, Meyer et al. (1977) found through research that legality pressure may lead to decoupling [15], and thus the company's response to external demand differs symbolically or substantively. Because the commitment of social responsibility requires the resources of the enterprise, the company may pretend that it is doing a good job in social responsibility through the dissemination policy, so that it obtains legitimacy, but if these policies are not mandatory, they may lead to the society of these enterprises. Responsibility fulfillment has the problem of "different words and deeds". Zajac and Westphal (2004) pointed out that most stakeholders will not seriously review the actual fulfillment of corporate social responsibility [16]. Therefore, due to the difficulty of stakeholders' access to information on the actual degree of fulfillment of corporate social responsibility and the lack of awareness, there will be a kind of social responsibility speculation. Okhmatovskiy and David also reached similar conclusions in their 2012 study. Some scholars have pointed out that the stronger the political connections of executives, the more they will be subject to more regulation, and therefore the lower the possibility of decoupling their behavior. And from a certain perspective, compared to executives without political connections. Executives with political connections are more concerned by stakeholders and so the public will pay 
more attention to them or their companies. In addition, this political connection may bring various informalities to the company. Government regulation, thereby increasing the exposure risk of its decoupling, so the quality of CSR reports of such companies will be better than those without political connections. Based on the above analysis, the following assumptions are made:

H3: There is a positive correlation between executive political relevance and CSR quality.

\subsection{The Influence of Regional Marketization Degree on the Political Relationship between Executives and the Quality of CSR}

Some scholars pointed out that from the perspective of institutional theory, visibility is an important factor in explaining the rejection of institutional pressure by organizational recipients (Ingram and Simon, 1995; Clemens and Douglas, 2005) [17] [18]. Some scholars have discovered through research that corporate visibility there is a positive correlation with the pressures or social expectations of the company. In addition, the higher the degree of regulation of laws and regulations in the region where the enterprise is located, the higher the degree of compliance of the company with social responsibility or its institutional pressure. Brandt and Li (2003) also pointed out in their research that the higher the degree of development of regional government institutions, the higher the degree of supervision that enterprises face. In addition, Tilcsik et al. [19] pointed out that the decoupling behavior of enterprises depends on the degree of external supervision (Tilcsik 2010) [20]. Due to the high degree of marketization in the region, the region has a relatively complete infrastructure, and the exposure frequency of enterprises is relatively high. Therefore, it is easier for all stakeholders to obtain timely and effective information on the company's social responsibility behavior. Secondly, in the areas with high marketization process, there are better intermediary services such as protection lawyers. Therefore, the stakeholders and legal rights of the market with higher marketization process can be better protected, and the quality of CSR reports issued by enterprises will be higher. Therefore, based on the above, the following assumptions are made:

H4: The regional marketization development process will positively adjust the relationship between executive political relations and reporting quality.

\section{Research Design}

\subsection{Sample Selection and Data Collection}

Since the measurement of regional marketization in this study is measured by the marketization index of each province in the "China Provincial Marketization Index Report" prepared by Fan Gang et al., the latest edition of the book is January 2017. Published, the most recent year for the marketization index of China's provinces released is 2016, so the sample data collection of this article is up to 2016. So this study collects information on the CSR social responsibility re- 
port issued by private companies from 2010 to 2016 and the rating data of RKS on the social responsibility report. In order to improve the quality of research, we directly deleted samples with missing multiple data, while retaining samples missing a small amount of data. For the study of the relationship between executive political relations and whether to issue social responsibility reports, this study selected all private enterprises from 2010 to 2016 as research samples, excluding enterprises that need to report on the private enterprises, SSE corporate governance, Shenzhen 100 Index Company, st and pt enterprises. Whether the company publishes the social responsibility report data comes from the downloading and sorting of the Wande database annual report. The score data of the corporate social responsibility report is from the report score of Rankins CSR Ratings. The regional marketization degree data comes from Fan Gang's report, other companies. Basic information data such as assets, profit, age, etc. are derived from the download and organization of Guotai'an database. The data related to the political relationship of executives come from the downloading of Guotaian's character database, and some of them are also from the public reports of various companies or others.

\subsection{Variable Definition and Measurement}

Independent variable

Because corporate executives cover a wide range of positions, the actual controllers of the company are mainly the chairman or general manager, and therefore mainly measure the political relationship between the chairman and the general manager. Therefore, drawing on Chen Shuangying and other practices, this article uses the chairman or general manager of the company to act as a deputy or a member of the National People's Congress or a government official to measure political connections. According to this, a politically-associated dummy variable is constructed. If the chairman or general manager has served or is currently a central government official, a CPPCC member, or a deputy to the National People's Congress, the variable is assigned a value of 5 . If he is a provincial government official, the CPPCC. For members, NPC deputies, etc., the variable is assigned a value of 4 . If you are a municipal and department official, a CPPCC member, an NPC representative, etc., the variable is assigned a value of 3 . If you are a county-level department, the variable is assigned a value of 2 . The variable is assigned a value of 1 if it is a government-level and below government position. If the executive has not or has not held the above positions, the variable is assigned a value of 0 .

Dependent variable

The release of CSR, because the release of the report is a non-negative relationship, this study constructs a dummy variable issued by CSR, which is 1 if the CSR report is issued, otherwise 0 . For the measurement of the quality of the report, this study used Christopher Marquis (2013) to select the M value (Macrocosm score of the report) and the total score in the RSK score data [21]. 


\section{Moderator}

The age of the enterprise is measured by the difference between the reporting year and the establishment time of the enterprise; the financial status is measured by the roa of the previous year of the reporting period, and the logarithm is taken; the degree of regional marketization development, with reference to the research of Jia Ming and Zhang Wei The marketization index data in the "China Marketization Index" compiled by Fan Gang et al.

In addition, the study also controls variables such as listed exchanges, industries, and firm size.

\section{Empirical Test and Analysis}

In order to verify the hypothesis of this study, and based on the characteristics of the sample data, this study used the statistical regression model of Stata 12.0 to analyze the relationship between political association and CSR report release, and used the Ols model to analyze the relationship between political association and report quality. The following is the result of data analysis.

\subsection{Descriptive Statistical Analysis}

Since there are two dependent variables in this study, the first one is the CSR report release, so the sample data for the first dependent variable relationship contains samples of companies that have not issued or published. The second dependent variable is the quality of the CSR report, so this type of sample can only be used by companies that have already published CSR reports. Therefore, the study in this paper has a total of two sample databases. Table 1 below is a descriptive statistical analysis of sample data of political associations and CSR report release relationships, and Table 2 is a descriptive statistical analysis of sample data of political associations and CSR report quality. Table 3 explains the abbreviations and references of various variables.

\subsection{Analysis of Regression Results}

Table 4 gives the analysis of the regression results of the independent variables on the CSR release. In order to ensure the robustness of the results, four models were made. M1 is the main effect model, M2 is the test adjustment variable rp model, M3 is the test adjustment variable ap model, and M4 is the full variable model including all variables. The results in the model show that the political relationship of executives has a significant positive impact on the release of CSR reports, and the relationship between the ages of enterprises has a significant regulatory effect, while the financial status of enterprises does not significantly regulate the relationship between the two. Therefore, $\mathrm{H} 1$ and $\mathrm{H} 2 \mathrm{a}$ are verified and $\mathrm{H} 2 \mathrm{~b}$ is not verified.

Table 5 gives the results of regression analysis of independent variables on CSR quality. Model 1 is the result of the influence of executive political association on the $M$ value (content score) of CSR, and model 2 is the influence of 
Table 1. Variable abbreviation and meaning.

\begin{tabular}{cccccc}
\hline variable & $\mathrm{N}$ & mean & $\mathrm{sd}$ & $\min$ & $\max$ \\
\hline csr & 3878 & 0.150 & 0.360 & 0 & 1 \\
po-1 & 3878 & 1.710 & 1.910 & 0 & 5 \\
lis & 3878 & 1.600 & 0.490 & 1 & 2 \\
ind & 3878 & 4.810 & 3.510 & 1 & 16 \\
age & 3878 & 2.850 & 0.280 & 1.790 & 4.190 \\
size & 3876 & 9.330 & 0.470 & 6.470 & 11.15 \\
roa & 3876 & 0.0300 & 0.320 & -16.11 & 7.250 \\
rp & 3878 & 0.0700 & 0.310 & -3.120 & 14.50 \\
ap & 3878 & 4.880 & 5.490 & 0 & 17.48 \\
\hline
\end{tabular}

Table 2. Descriptive statistical analysis of major variables.

\begin{tabular}{cccccc}
\hline variable & $\mathrm{N}$ & mean & sd & min & $\max$ \\
\hline m-val & 448 & 12.10 & 3.640 & 3.280 & 22.27 \\
po-1 & 441 & 2.180 & 1.840 & 0 & 5 \\
m-p & 448 & 17.02 & 15.14 & -1.200 & 49.55 \\
lis & 448 & 1.770 & 0.420 & 1 & 2 \\
ind & 448 & 5.410 & 4 & 1 & 16 \\
size & 448 & 9.520 & 0.460 & 8.550 & 11.04 \\
tot-score & 447 & 35.18 & 9.030 & 15.56 & 61.46 \\
mar-in & 448 & 7.910 & 1.600 & -0.300 & 9.950 \\
\hline
\end{tabular}

Table 3. Variable abbreviation and meaning.

\begin{tabular}{|c|c|}
\hline Pronoun & Meaning \\
\hline CSR & Whether to publish CSR report \\
\hline po-1 & Political association level \\
\hline lis & Listed exchange \\
\hline ind & industry \\
\hline age & Business age \\
\hline size & Business scale \\
\hline roa & Financial status \\
\hline $\mathrm{rp}$ & Financial status and political association \\
\hline ap & Business age and political connections \\
\hline m-val & The $\mathrm{m}$ value reported by CSR \\
\hline tot-score & Total score of CSR report \\
\hline mar-in & Regional marketization index \\
\hline $\mathrm{m}-\mathrm{p}$ & Regional marketization index and political association \\
\hline
\end{tabular}


Table 4. The impact of political connection on CSR release.

\begin{tabular}{|c|c|c|c|c|}
\hline & (1) & (2) & (3) & (4) \\
\hline & $\mathrm{m} 1$ & $\mathrm{~m} 2$ & $\mathrm{~m} 3$ & $\mathrm{~m} 4$ \\
\hline VARIABLES & $\operatorname{csr}$ & $\operatorname{csr}$ & $\operatorname{csr}$ & $\operatorname{csr}$ \\
\hline \multirow[t]{2}{*}{ Po-L } & $0.115^{* * *}$ & $0.113^{\star * *}$ & $1.106^{* * *}$ & $1.108^{\star * *}$ \\
\hline & $(3.72 \mathrm{e}-07)$ & $(0.000513)$ & $(4.29 \mathrm{e}-06)$ & $(4.20 \mathrm{e}-06)$ \\
\hline \multirow[t]{2}{*}{$\mathrm{rp}$} & & 0.0466 & & -0.0222 \\
\hline & & $(0.926)$ & & $(0.964)$ \\
\hline \multirow[t]{2}{*}{ lis } & $0.634^{* * *}$ & $0.635^{\star * \star}$ & $0.628^{* * *}$ & $0.627^{\star \star \star}$ \\
\hline & $(2.10 \mathrm{e}-10)$ & $(2.19 \mathrm{e}-10)$ & $(2.98 \mathrm{e}-10)$ & $(3.13 e-10)$ \\
\hline \multirow[t]{2}{*}{ ind } & $0.0503^{\star * *}$ & $0.0503^{\star * *}$ & $0.0506^{\star * *}$ & $0.0506^{\star * *}$ \\
\hline & $(0.000103)$ & $(0.000103)$ & $(8.93 e-05)$ & $(8.77 \mathrm{e}-05)$ \\
\hline \multirow[t]{2}{*}{ age } & -0.00360 & -0.00420 & $0.801^{* * *}$ & $0.803^{* * *}$ \\
\hline & $(0.983)$ & $(0.980)$ & $(0.00192)$ & $(0.00172)$ \\
\hline \multirow[t]{2}{*}{ size } & $1.071^{* * *}$ & $1.072^{\star * \star}$ & $1.070^{* * *}$ & $1.070^{\star * \star}$ \\
\hline & (0) & (0) & (0) & (0) \\
\hline \multirow[t]{2}{*}{ roa } & 2.187 & 2.118 & 2.262 & 2.295 \\
\hline & $(0.385)$ & $(0.294)$ & $(0.375)$ & $(0.271)$ \\
\hline \multirow[t]{2}{*}{ ap } & & & $-0.346^{* * *}$ & $-0.347^{* * *}$ \\
\hline & & & $(3.84 \mathrm{e}-05)$ & $(3.56 \mathrm{e}-05)$ \\
\hline \multirow[t]{2}{*}{ Constant } & $-13.39^{\star * *}$ & $-13.40^{* * *}$ & $-15.69^{\star * \star}$ & $-15.69^{\star * *}$ \\
\hline & (0) & (0) & (0) & (0) \\
\hline Observations & 3,876 & 3,876 & 3,876 & 3,876 \\
\hline
\end{tabular}

Robust pval in parentheses. ${ }^{* *} \mathrm{p}<0.01,{ }^{* *} \mathrm{p}<0.05,{ }^{*} \mathrm{p}<0.1$.

executive political association on the $\mathrm{M}$ value (content score) of CSR after adding the regulatory variable-regional marketization development process. As a result, model 3 is the result of the influence of executive political association on the total score of CSR, and model 4 is the result of the influence of executive political association on the total score of CSR after the adjustment variable-regional marketization development process. From the analysis results, all results were significant at $1 \%$, assuming $\mathrm{H} 3 \mathrm{a}, \mathrm{H} 3 \mathrm{~b}$, and $\mathrm{H} 4$ were verified.

\section{Conclusions}

This study manually collects and organizes Chinese private listed companies from 2010 to 2016 by manually collecting and arranging the political correlation data of executives of Chinese private listed companies, and experimentally tests the impact of executive political relations on the release of CSR reports and the 
Table 5. The impact of political connection on the quality of CSR reporting.

\begin{tabular}{ccccc}
\hline & $(1)$ & $(2)$ & $(3)$ & $(4)$ \\
\hline VARIABLES & M-value & M-value & Total-score & Total-score \\
\hline Polity-Level & $0.0310^{* * *}$ & $-1.150^{* * *}$ & $0.360^{* * *}$ & $-2.228^{* *}$ \\
& $(0.743)$ & $(0.00407)$ & $(0.131)$ & $(0.0207)$ \\
mp & & $0.151^{* * *}$ & & $0.331^{* * *}$ \\
lis & & $(0.00181)$ & & $(0.00449)$ \\
& $-0.735^{*}$ & -0.579 & 0.0351 & 0.377 \\
ind & $(0.0507)$ & $(0.156)$ & $(0.969)$ & $(0.703)$ \\
& $-0.200^{* * *}$ & $-0.175^{* * *}$ & $-0.517^{* * *}$ & $-0.463^{* * *}$ \\
size & $(7.60 \mathrm{e}-06)$ & $(0.000176)$ & $(4.58 \mathrm{e}-07)$ & $(1.33 \mathrm{e}-05)$ \\
& $1.128^{* * *}$ & $1.056^{* *}$ & 1.236 & 1.078 \\
& $(0.00805)$ & $(0.0138)$ & $(0.240)$ & $(0.304)$ \\
R-squared & 3.682 & 3.921 & $25.42^{* *}$ & $25.94^{* *}$ \\
Constant & $(0.381)$ & $(0.360)$ & $(0.0156)$ & $(0.0142)$ \\
& 440 & 440 & 440 & 440 \\
\hline Rorvations & 0.068 & 0.102 & 0.061 & 0.088 \\
\hline
\end{tabular}

Robust pval in parentheses. ${ }^{* * *} \mathrm{p}<0.01,{ }^{* *} \mathrm{p}<0.05,{ }^{*} \mathrm{p}<0.1$.

quality of reports. The results of the study indicate that executive political connections have a significant positive impact on the quality of CSR report releases and reports. The enlightenment given by the research results is that the government can fulfill the social responsibility obligations by encouraging and guiding enterprises with political connections to the stage where the government has not listed the social responsibility report as mandatory, become a model of the industry, and then drive other companies to join the voluntary social responsibility team.

Since the measurement of executives' political connections in this study only measures the political relationship between the chairman and the general manager, it does not study the effect of the senior management team's political connections on corporate social responsibility behaviors; secondly, the research is not political. The types of associations are divided, and studies have shown that different types of political connections have different effects on the behavior of enterprises. Therefore, the author hopes that other scholars can improve the research in this part in future research.

\section{Conflicts of Interest}

The author declares no conflicts of interest regarding the publication of this paper. 


\section{References}

[1] Baron, D.P. (1995) Integrated Strategy: Market and Nonmarket Components. California Management Review, 37, 47-65. https://doi.org/10.2307/41165788

[2] Schuler, D.A. and Rehbein, K, (1997) The Filtering Role of the Firm in Corporate Political Involvement. Business \& Society, 36, 116-139. https://doi.org/10.1177/000765039703600202

[3] Hillman, A.J. and Dalziel, T. (2004) Boards of Directors and Firm Performance: Integrating Agency and Resource Dependence Perspectives. Academy of Management Review, 28, 383. https://doi.org/10.5465/amr.2003.10196729

[4] Salancik, G.R. and Pfeffer, J. (1978) A Social Information Processing Approach to Job Attitudes and Task Design. Administrative Science Quarterly, 23, 224-253. https://doi.org/10.2307/2392563

[5] Fan, J.P.H., Wong, T.J. and Zhang, T. (2007) Politically Connected CEOs, Corporate Governance, and Post-IPO Performance of China's Newly Partially Privatized Firms. Journal of Financial Economics, 84, 330-357.

https://doi.org/10.1016/j.jfineco.2006.03.008

[6] Detomasi, D.A. (2008) The Political Roots of Corporate Social Responsibility. Journal of Business Ethics, 82, 807-819. https://doi.org/10.1007/s10551-007-9594-y

[7] Tian, L.H. and Zhang, W. (2013) The Three Major Effects of Political Associations on the Long-Term Performance of Listed Companies in China. Economic Research.

[8] Zhang, J.J. and Zhang, Z.X. (2005) Political Strategies of Chinese Private Entrepreneurs. Management World.

[9] Kim, Y. and Cannella Jr., A.A. (2008) Toward a Social Capital Theory of Director Selection. Corporate Governance: An International Review, 16.

https://doi.org/10.1111/j.1467-8683.2008.00693.x

[10] Barnett (2007) Stakeholder Influence Capacity and the Variability of Financial Returns to Corporate Social Responsibility. Academy of Management Review, 32.

[11] Marquis, C. and Tilcsik, A. (2013) Imprinting: Toward a Multilevel Theory. Academy of Management Annals, 7, 193-243. https://doi.org/10.5465/19416520.2013.766076

[12] Kriauciunas, A. and Kale, P. (2006) The Impact of Socialist Imprinting and Search on Resource Change: A Study of Firms in Lithuania. Strategic Management Journal, 27, 659-679. https://doi.org/10.1002/smj.537

[13] Hillman, A.J. (2005) Politicians on the Board of Directors: Do Connections Affect the Bottom Line? Journal of Management, 31, 464-481.

https://doi.org/10.1177/0149206304272187

[14] Seifert, B., Morris, S.A. and Bartkus, B.R. (2004) Having, Giving, and Getting: Slack Resources, Corporate Philanthropy, and Firm Financial Performance. Business \& Society.

[15] Meyer, J.W. and Rowan, B. (1977) Institutionalized Organizations: Formal Structure as Myth and Ceremony. American Journal of Sociology, 83. https://doi.org/10.1086/226550

[16] Zajac, E.J. and Westphal, J.D. (2004) The Social Construction of Market Value: Institutionalization and Learning Perspectives on Stock Market Reactions. American Sociological Review, 69, 433-457. https://doi.org/10.1177/000312240406900507

[17] Ingram, P. and Simons, T. (1995) Institutional and Resource Dependence Determinants of Responsiveness to Work-Family Issues. Academy of Management Journal, 38, 1466-1482. 
[18] Clemens, B.W. and Douglas, T.J. (2005) Understanding Strategic Responses to Institutional Pressures. Journal of Business Research, 58, 1205-1213.

https://doi.org/10.1016/j.jbusres.2004.04.002

[19] Brandt, L. and Li, H. (2003) Bank Discrimination in Transition Economies: Ideology, Information, or Incentives? Journal of Comparative Economics, 31, 387-413. https://doi.org/10.1016/S0147-5967(03)00080-5

[20] Tilcsik, A. (2010) From Ritual to Reality: Demography, Ideology, and Decoupling in a Post-Communist Government Agency. Academy of Management Journal, 53, 1474-1498. https://doi.org/10.5465/amj.2010.57318905

[21] Christopher, M. and Cuili, Q. (2013) Corporate Social Responsibility Reporting in China: Symbol or Substance? Organization Science, 25, 127-148. 